\title{
Parasites of the mangrove mussel Mytella guyanensis (Bivalvia: Mytilidae) in Camamu Bay, Bahia, Brazil
}

\author{
Ceuta, LO. and Boehs, G.* \\ Programa de Pós-graduação em Sistemas Aquáticos Tropicais, Departamento de Ciências Biológicas - DCB, \\ Universidade Estadual de Santa Cruz - UESC, Rod. Ilhéus-Itabuna, Km 16, CEP 45650-900, Ilhéus, BA, Brazil \\ *e-mail: guislaboehs@hotmail.com \\ Received March 30, 2011 - Accepted September 19, 2011 - Distributed August 31, 2012
}

(With 7 figures)

\begin{abstract}
This contribution reports the parasites found in the mangrove mussel Mytella guyanensis in Camamu Bay, Bahia, Brazil. Samples were collected monthly from September 2006 through October 2007. A total of 460 individuals were collected, fixed in Davidson's solution, and processed by standard histological techniques, and the sections were stained with Harris hematoxylin and eosin (H\&E). The water temperature ranged from 23.5 to $31.6^{\circ} \mathrm{C}$, and the salinity from 25 to $37 \%$. Microscopic analysis showed Rickettsia-like organisms (RLOs), Nematopsis sp. (Apicomplexa), and Platyhelminthes, including a turbellarian, sporocysts of Bucephalus sp., metacercariae, and metacestodes of Tylocephalum sp. Parasites were observed mainly in the gills, mantle, and digestive gland. The prevalence of Nematopsis sp. was $100 \%$, and in heavily infected mussels the tissues of the labial palps were damaged. RLOs occurred in high prevalence and intensity of infection in some periods. The digenean sporocysts showed moderate prevalence but high intensity of infection, and caused parasitic castration. In general, there was no significant spatial or temporal variation $(p>0.05)$ of the parasites, which is probably attributable to the small variations of temperature and salinity in the region.
\end{abstract}

Keywords: mollusc health, Northeastern Brazil, Rickettsia, Nematopsis, Bucephalus.

\section{Parasitos do marisco-do-mangue, Mytella guyanensis (Bivalvia: Mytilidae), na Baía de Camamu, Bahia}

\begin{abstract}
Resumo
Neste estudo, foram investigados os parasitos de Mytella guyanensis da Baía de Camamu (BA). As amostragens foram feitas mensalmente entre setembro de 2006 e outubro de 2007 e totalizaram 460 animais, que foram fixados em solução de Davidson e processados por técnica rotineira de histologia, com inclusão em parafina e coloração por hematoxilina de Harris e eosina. Foram evidenciados organismos assemelhados a Rickettsia (RLOs); Nematopsis sp. (Apicomplexa) e Platyhelminthes, incluindo um turbelário, esporocistos de Bucephalus sp. e o cestoide Tylocephalum sp. Os parasitos foram encontrados principalmente nas brânquias, no manto e na glândula digestiva. Todos os animais apresentaram Nematopsis sp., o que causou alteração nos palpos labiais em exemplares com alta infecção. RLOs ocorreram em alta prevalência e intensidade de infecção em alguns períodos. Esporocistos de trematódeos digenéticos, com prevalência moderada, mostraram-se em alta intensidade de infecção e causaram castração parasitária. Não houve variação temporal e espacial significativa $(\mathrm{p}>0,05)$ dos parasitos, o que provavelmente se deveu à pequena amplitude de variação da temperatura e da salinidade na região.
\end{abstract}

Palavras-chave: saúde de moluscos, Nordeste do Brasil, Rickettsia, Nematopsis, Bucephalus.

\section{Introduction}

Knowledge of parasites and pathogens of molluscs allows the management of natural stocks and disease control in commercially cultured species. Various viruses, bacteria, protists, fungi, and metazoans can parasitise molluscs, often affecting their health and endangering their survival. According to information obtained in several studies (Narchi, 1966; Umiji et al., 1976; Nascimento et al., 1986; Azevedo and Matos, 1999; Boehs and Magalhães, 2004;

Sabry and Magalhães, 2005; Sabry et al., 2007; Garcia and Magalhães, 2008; Pinto and Boehs, 2008; Da Silva et al., 2009; Boehs et al., 2010), the most common parasites of the molluscs of economic interest from the Brazilian coast are gregarines of the genus Nematopsis, which use bivalves as intermediate hosts and complete their life cycle in crustaceans (Lauckner, 1983); digeneans, which also use molluscs as intermediate hosts; and the polychaete 
Polydora websteri Hartman, 1943 (Spionidae), which occurs mainly in oysters of the genus Crassostrea.

The mangrove mussel Mytella guyanensis (Lamarck, 1819) (Bivalvia: Mytilidae) is distributed from Mexico to Peru in the Pacific Ocean, and from Venezuela to Brazil in the Atlantic Ocean (Rios, 2009). It inhabits intertidal zones, attaching to mangrove roots with the byssus, mainly on the red mangrove Rhizophorae mangle L. Along the Brazilian coast it is exploited as a source of food and for commercial sale, and in some places it is beginning to be cultivated. Little is known about parasites associated with this species. In northern Brazil, Azevedo and Matos (1999) described a new species of gregarine associated with M. guyanensis (Nematopsis mytella), and Matos et al. (2005) recorded the protozoan Steinhausia mytilovum (Field, 1924) (Microspora) in this species. Pinto and Boehs (2008) observed Nematopsis sp.; and Boehs et al. (2010) found RLOs, Nematopsis sp. and sporocysts of a species of Bucephalidae in M. guyanensis from the Cachoeira River (Bahia, northeastern Brazil); there are, so far, no other records.

Camamu Bay, located in southern Bahia, has an area of approximately $380 \mathrm{~km}^{2}$ and is the third-largest bay in Brazil. In its surroundings are lush mangroves and small towns with fewer than 30,000 inhabitants including Camamu, Maraú, and Barra Grande, whose residents live on fishing, tourism, and services. In the same region, about 20 traditional communities live from fishing and from harvesting crustaceans and molluscs and palm (dendê) oil. The bay is located in an environmental protection area (APA Camamu), and human disturbance to the biota of the estuary has so far been minimal. This study aimed to record the parasites, as well as their prevalence, intensity of infection, and histopathology in M. guyanensis from this region.

\section{Material and Methods}

Samples were collected between September 2006 and October 2007 at two fixed collecting stations in Camamu Bay. Station (St) 1 was farther from (13 59' $92^{\prime \prime} \mathrm{S}$ and $\left.38^{\circ} 58^{\prime} 17^{\prime \prime} \mathrm{W}\right)$, and St 2 nearer the entrance to the estuary $\left(13^{\circ} 56^{\prime} 05^{\prime \prime} \mathrm{S}\right.$ and $\left.38^{\circ} 58^{\prime} 58^{\prime \prime} \mathrm{W}\right)$. Twenty individuals of $M$. guyanensis were collected monthly from each sampling station. Water temperature and salinity were recorded while sampling, using a standard mercury thermometer and a handheld refractometer (Atago S/ Mill). In the laboratory, the specimens were measured for length (antero-posterior axis) with a digital caliper, and then shucked and examined for macroscopic anomalies. A 5-mm cross section (including gills, foot, and visceral mass) was made and fixed in Davidson's solution (Shaw and Battle, 1957) for 24 hours, dehydrated in an ethanol series, embedded in paraffin, sectioned ( $7 \mu \mathrm{m}$ thick) and stained with Harris hematoxylin and eosin (H\&E). Sections were examined under light microscopy. We used 460 mussels, which measured between 3.5 and $6.2 \mathrm{~cm}$. An additional collection of 100 mussels was made in
March 2010, at St1, with the aim of identifying digenetic trematodes observed in previous samples. They were kept in individual bottles containing seawater for 24 hours to allow the cercariae to emerge, after which they were dissected. Larvae were stained with Nile blue and analyzed fresh, under a stereomicroscope.

The prevalence of each parasite was calculated according to Margolis et al. (1982), as follows: numbers of individuals infected divided by the total number of individuals in the sample, expressed as a percentage. The stereological technique proposed by Lowe et al. (1994), using a Weibel graticule, was used to calculate the intensity of infection by digeneans. To this end, from five fields of the mantle of each infected mussel, we calculated the mean area occupied by the parasite tissue (PT). The results were analysed according to the following classification: light infection $=<5 \%$ of PT; moderate $=5-25 \%$; high $=25-50 \%$; and very high $=>50 \%$. Except for parasites with low frequency or maximum prevalence, the Chi-square and Mann-Whitney tests were used to identify significant differences in the prevalence of parasites and abiotic factors on temporal and spatial scales, respectively. The Spearman test was used to investigate possible relationships between variations in the prevalence of parasites and abiotic factors. The significance level adopted was $95 \%$.

\section{Results}

The average temperature was $28.0{ }^{\circ} \mathrm{C}(\mathrm{SD} \pm 2.5)$ at St 1 and $28.2{ }^{\circ} \mathrm{C}(\mathrm{SD} \pm 2.1)$ at $\mathrm{St} 2$. The average salinity was $30.6 \%$ ( $\mathrm{SD} \pm 3$ ) and $33.4 \%$ ( $\mathrm{SD} \pm 2.8)$, respectively. There were no spatial and temporal variations $(\mathrm{p}>0.05)$ in these factors (Table 1).

Microscopic analysis of tissues showed bacteria, protozoa, and metazoans associated with $M$. guyanensis, in varying levels of prevalence and degrees of infection. Rickettsia-like organisms (RLOs) were observed in mussels from both sampling stations, with a similar prevalence ( $p>0.05$ ) between them. At St 2 there was significant temporal variation $(\mathrm{p}<0.05)$, but no evidence of any pattern (Table 1). The colonies of RLOs were observed in the epithelium of the digestive gland (Figure 1) and in the gills. We counted from 1-48 colonies per histological section in the digestive gland and 1-18 colonies in the gills. The diameters ranged from 7-21 $\mu \mathrm{m}(\mathrm{n}=15)$ and $16-49 \mu \mathrm{m}(\mathrm{n}=15)$, respectively. Hypertrophy and cell lysis occurred in both organs. The correlation between the prevalence of RLOs and abiotic factors was not significant $(\mathrm{R}<0.3, \mathrm{p}>0.05)$.

Intrahemocytic oocysts of the genus Nematopsis Schneider, 1892 (Apicomplexa: Eugregarinida: Porosporidae) were observed in all mussels (Table 1). The most frequent sites of occurrence of this parasite were the gills, mantle, and labial palps, and less frequently the digestive gland and foot. Generally, each phagocyte contained 1-3 oocysts, but in some cases up to 8 . The oocysts had a mean length of $7.7 \mu \mathrm{m}(\mathrm{SD} \pm 1.4, \mathrm{n}=30)$ and their number per histological section was $1-38($ mean $=3.7, \mathrm{SD} \pm 3.5, \mathrm{n}=230)$ in the 
gills and 1-47 (mean $=4.6, \mathrm{SD} \pm 6.1, \mathrm{n}=150)$ in the mantle. In the labial palps of some mussels, there was a high intensity of infection (more than 200 oocysts per histological section) and destruction of connective tissue (Figure 2).

An unidentified turbellarian was observed in the gills, in low prevalence and intensity of infection, at St1 (1/histological section) (Figure 3).

Sporocysts of Bucephalus sp. (Digenea: Bucephalidae) were found in low prevalence at St1 (Table 1, Figure 4a), and in this case, there was macroscopic evidence of this

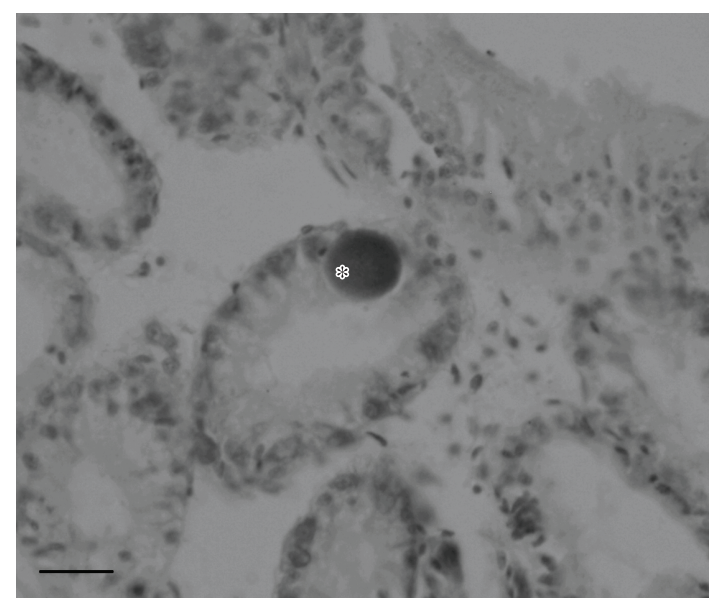

Figure 1. Colony of Rickettsia-like organisms (*) in the digestive gland of Mytella guyanensis. Scale bar $=20 \mu \mathrm{m}$. bucephalosis, consisting of the fibrous appearance and orange color of the mantle. The infection rate was high (49.5\% parasite tissue - PT) or very high $(84.8 \%$ of PT), and there was evidence of parasitic castration. The presence of this fluke was confirmed by the technique of cercariae emergence (Figure 4b, c). A second, unidentified trematode, possibly belonging to another family of Digenea, was observed in the two locations, with a higher prevalence than Bucephalus; and in this case, in addition to the germ

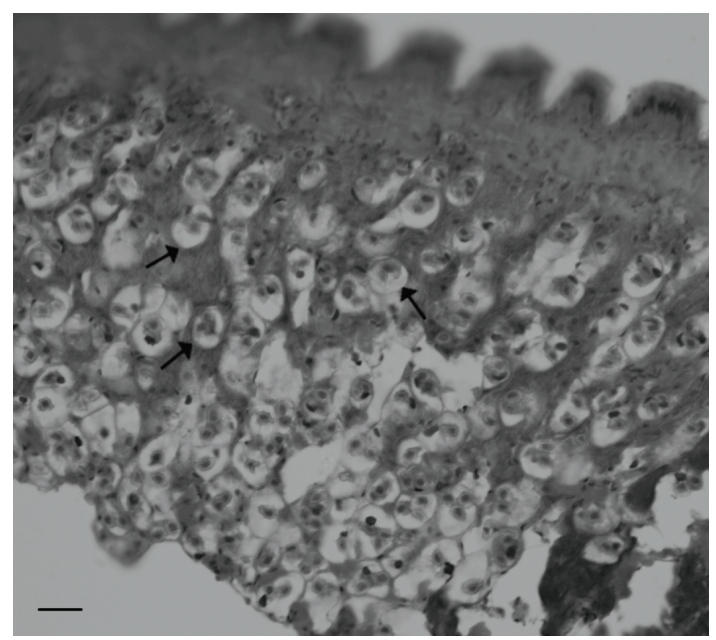

Figure 2. Multiple phagocytes (arrows) containing oocysts of Nematopsis sp. in the labial palps of Mytella guyanensis, showing destruction of connective tissue. Scale bar $=20 \mu \mathrm{m}$.

Table 1. Abiotic factors, parasites, and their prevalences (\%) in Mytella guyanensis at two sites in Camamu Bay (Bahia), and significance ( $\mathrm{p}$ value) of the Chi-square $\left(\chi^{2}\right)$ and Mann-Whitney (MW) tests for temporal and spatial variation, respectively. Period: September 2006 through October 2007.

\begin{tabular}{|c|c|c|c|c|c|c|c|c|c|c|c|c|c|c|}
\hline \multirow{2}{*}{ Months } & \multicolumn{9}{|c|}{ St1 $(n=240)$} & \multicolumn{5}{|c|}{ St2 $(n=220)$} \\
\hline & $\mathbf{T}$ & $\mathbf{S}$ & $\mathbf{R L}$ & $\mathrm{Ne}$ & UTu & $\mathbf{B u}$ & UDi & UMe & $\mathbf{T y}$ & $\mathbf{T}$ & $\mathbf{S}$ & $\mathbf{R L}$ & $\mathrm{Ne}$ & UDi \\
\hline Sept. & 26 & 29 & 30 & 100 & 5 & - & 10 & 5 & - & & & & & \\
\hline Oct. & 29.3 & 30 & 10 & 100 & 5 & - & 5 & - & - & & & & & \\
\hline Nov. & 29.2 & 34 & 10 & 100 & - & - & - & - & - & 27 & 37 & 5 & 100 & 25 \\
\hline Dec. & 31 & 35 & 10 & 100 & 5 & - & 15 & - & - & 29 & 36 & 25 & 100 & - \\
\hline Jan. & 29 & 32 & - & 100 & - & - & - & - & 5 & 30 & 35 & - & 100 & 10 \\
\hline Feb. & 29 & 33 & 20 & 100 & - & 10 & - & - & - & 30 & 37 & 45 & 100 & 5 \\
\hline Mar. & 30 & 25 & 15 & 100 & - & - & - & - & - & 31 & 30 & 25 & 100 & 10 \\
\hline Apr. & 31.6 & 34 & 10 & 100 & - & - & - & - & - & 30.5 & 34 & 15 & 100 & 5 \\
\hline May & 27.5 & 29 & - & 100 & - & - & - & - & - & 27.7 & 30 & 20 & 100 & 15 \\
\hline June & 24.6 & 30 & 25 & 100 & - & - & 5 & - & - & 25.4 & 32 & 35 & 100 & - \\
\hline July & 25.9 & 27 & - & 100 & - & - & 5 & - & - & 28.6 & 30 & 5 & 100 & - \\
\hline Aug. & 23.5 & 29 & 5 & 100 & - & - & - & - & - & 24.5 & 31 & 15 & 100 & 5 \\
\hline Sept. & & & & & & & & & & 27 & 35 & 50 & 100 & 10 \\
\hline $\mathrm{TP}$ & & & 11.25 & 100 & 1.25 & 0.83 & 3.33 & 0.42 & 0.42 & & & 21.36 & 100 & 7.73 \\
\hline (p) $\chi^{2}$ & 0.99 & 0.98 & 0.75 & - & - & - & 0.06 & - & & 0.99 & 0.99 & 0.01 & & 0.09 \\
\hline (p) MW & & $\mathrm{T}=0.9$ & & & $S=0.0$ & & & $\mathrm{~L}=0.1$ & & & & $\mathrm{Di}=0.1$ & & \\
\hline
\end{tabular}

$\mathrm{T}=$ Temperature $\left({ }^{\circ} \mathrm{C}\right) ; \mathrm{S}=$ Salinity $(\%) ; \mathrm{RL}=$ Rickettsia-like organisms; $\mathrm{Ne}=$ Nematopsis; Utu = Unidentified Turbellaria; $\mathrm{Bu}=$ Bucephalus sp; UDi = Unidentified Digenea; Ume = Unidentified metacercariae; Ty $=$ Tylocephalum; $\mathrm{TP}=\mathrm{Total}$ prevalence; (-) Not detected. 
masses and cercariae, there was evidence of the presence of metacercariae (Table 1, Figure 5). In most mussels infected by this trematode, the degree of infection was high or very high and parasitic castration was evident. Only $8 \%$ of infected mussels still contained a few follicles and gametes. There was no significant spatial or temporal variation of this trematode (Table 1) and no significant correlation between this and the abiotic factors.

An unidentified metacercaria was found in the mantle of an individual from St1, which showed the beginning of encapsulation and infiltration of hemocytes (Figure 6).

A metacestode of genus Tylocephalum Linton, 1890 (Tetragonocephalidae) was observed in the mantle of a mussel from St1, showing encapsulation and infiltration (Figure 7).

\section{Discussion}

The resemblance in the occurrence and prevalence of parasites at the two sampling stations reflects the geographical proximity and similar environmental conditions. The narrow range of temperature and salinity throughout the year and the absence of well-defined seasonal patterns,

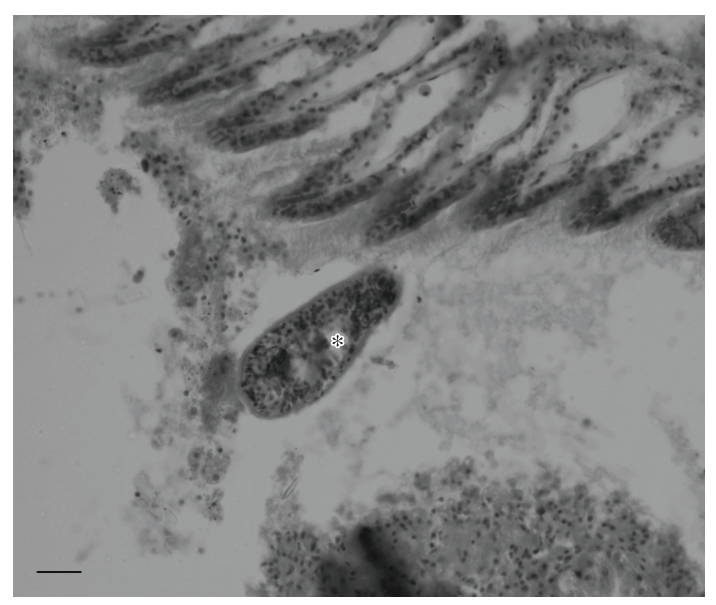

Figure 3. Unidentified turbellarian (*) in the gills of Mytella guyanensis. Scale bar $=20 \mu \mathrm{m}$. characteristic of the southern coast of Bahia as observed in a previous study (Boehs et al., 2010), account for the observed absence of any pattern of temporal variation of the parasites.

Infections in bivalve molluscs caused by Rickettsia-like organisms (RLOs) are generally reported as being of low intensity and not associated with disease (Bower et al., 1994), but some appear to be capable of causing disease and possibly death in molluscs (Lauckner, 1983). In the present study, the infected cells showed hypertrophy, with some cases of cell lysis. Similar localized effects were observed by Boehs et al. (2010) in this same species, as in other bivalves by Villalba et al. (1997), Carballal et al. (2001), and Cremonte et al. (2005). However, Villalba et al. (1999) found serious damage including disorganization of the gill architecture and mass mortality in Venerupis rhomboides (Pennant, 1777) caused by these organisms. In this study, during one month the prevalence of RLOs rose to $50 \%$ of the mussels, and some contained more than 50 colonies per histological section. These observations and the reports of Lauckner (1983) in Tellina tenuis (da Costa, 1758) and of Villalba et al. (1999) in V. rhomboides indicate that RLOs should not be overlooked as potentially harmful to populations of marine bivalves, especially if they occur concomitantly with other pathogens.

Despite the high prevalence of the gregarine Nematopsis sp., the intensity of infection was generally low, with no apparent injury to the host. However, in some mussels with intense infection in the labial palps, there was architectural disorganization of the connective tissue at this location. This very likely compromises the functioning of this organ, interfering with feeding. High prevalence of these gregarines were also found in M. guyanensis elsewhere on the Brazilian coast (Azevedo and Matos, 1999; Pinto and Boehs, 2008), as well as in the mussel Perna perna (L., 1758) (Lima et al., 2001) and the mangrove oyster Crassostrea rhizophorae (Guilding, 1828) (Nascimento et al., 1986; Sabry and Magalhães, 2005; Sabry et al., 2007), but none of these studies noted serious damage caused by this parasite. This contrasts with the situation observed in Cerastoderma edule (L., 1758) by Azevedo and Cachola (1992), who attributed massive
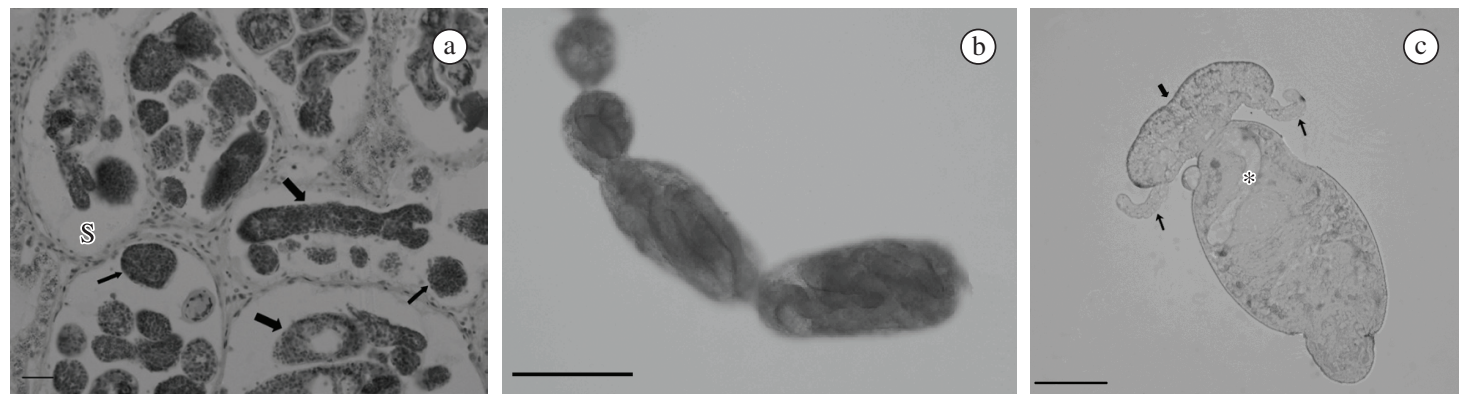

Figure 4. Bucephalus sp. in Mytella guyanensis. (a) Histological section of the gonads with sporocysts (S) containing germ balls (small arrows) and cercariae (large arrows); (b) Branched sporocyst of Bucephalus sp. containing cercariae; (c) Developing cercariae of Bucephalus sp., showing the short wide base of the tail (large arrow), forked tail (arrow), and excretory vesicle as a blind sac (*). Scale bar: A $=20 \mu \mathrm{m}$; B and $\mathrm{C}=50 \mu \mathrm{m}$. 
mortality in the bivalve to Nematopsis sp. The occurrence of the gregarine mainly in the gills and mantle confirms previous observations in other bivalves (Carballal et al., 2001; Sabry et al., 2007; Pinto and Boehs, 2008). Boehs et al. (2010) also related the high prevalence of Nematopsis to the occurrence of abundant crustaceans, the definitive hosts of these gregarines, as is the case in this bay.

Turbellarians associated with molluscs are reported in the mantle cavity or in the gut, where they cause no significant damage to their hosts (Lauckner, 1983; Bower, 1992). However, when present in large numbers, these flatworms can cause intense hemocytic infiltration and mechanical damage to the gills (Robledo et al., 1994; Villalba et al., 1997; Francisco et al., 2010). In this study, there was no evidence of damage, since these organisms were found in low intensities of infection.

With respect to the digenetic trematodes, the simultaneous presence of cercariae and metacercariae observed in this

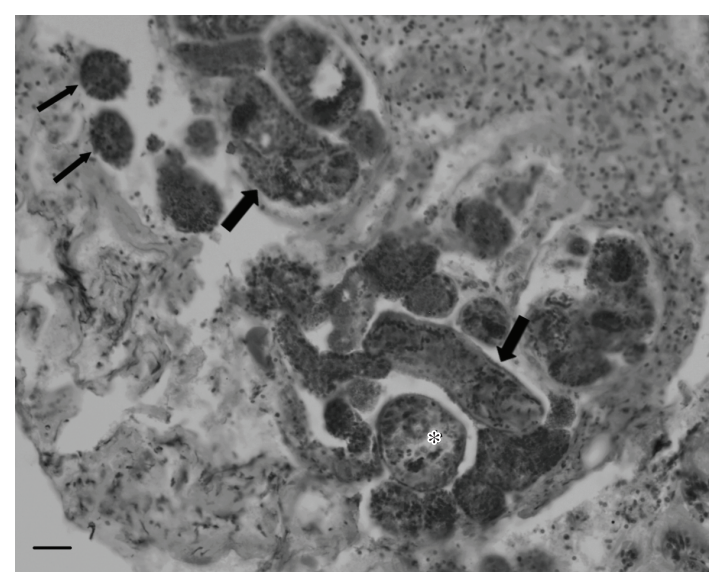

Figure 5. Unidentified digenean sporocysts in Mytella guyanensis, containing germ balls (small arrows), cercariae (large arrows), and metacercaria $\left(^{*}\right)$ in the gonad. Scale bar $=20 \mu \mathrm{m}$.

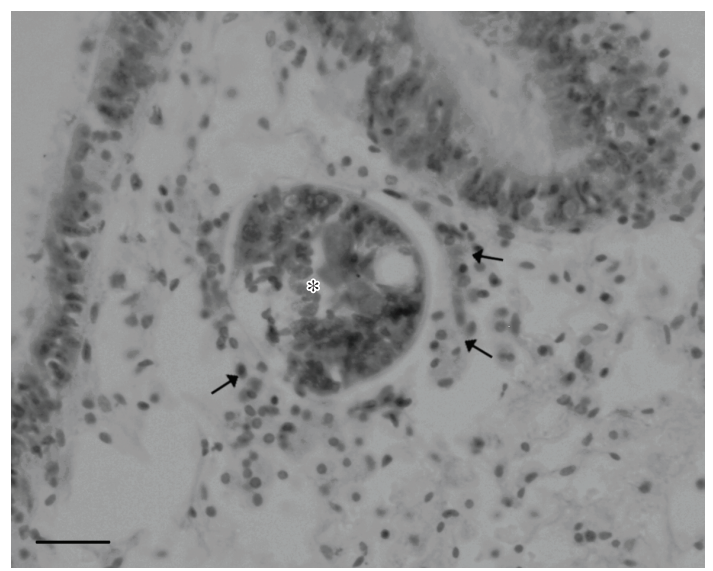

Figure 6. Digenean metacercaria $(*)$ in the mantle of Mytella guyanensis, showing hemocyte infiltration (arrows). Scale bar $=20 \mu \mathrm{m}$. study confirms that bivalves can serve as primary and secondary intermediate hosts at the same time, as previously reported (Paperna, 1995). Most infected mussels showed a high degree of infection and evidence of parasitic castration. This can be caused by mechanical and physiological damage (Cheng and Burton, 1965; Winstead et al., 2004). According to Bower et al. (1994), the presence of many sporocysts reduces the energy efficiency of the circulatory system, causing disturbances in gametogenesis. A limited or lack of host response seems to be a feature of infections caused by bucephalids. In M. guyanensis analysed by Boehs et al. (2010), in contrast to our findings, infiltration of hemocytes was present around some dead or degenerating sporocysts. In $P$. perna, a hemocytic reaction was seen in severely infected individuals (Da Silva et al., 2002). In Protothaca antiqua (King and Broderip, 1853), the sporocysts were surrounded by a dense infiltration of hemocytes; however, this reaction was considered unusual (Cremonte et al., 2005). Unlike sporocysts, metacercaria usually do not cause significant damage or parasitic castration (Lauckner, 1983; Bower et al., 1994; Boehs et al., 2010), which was also evident in our results. However, shell lesions, tissue hypertrophy, and compression of adjacent tissues have been reported in some studies (Bower et al., 1994; Carballal et al., 2001; Cremonte et al., 2005). Therefore, in the sporocyst stage, the high potential for inhibiting defense mechanisms and destroying tissue increases the pathogenic potential of bucephalids and other trematodes.

The site of occurrence of Tylocephalum sp. in the present study was the mantle; in Anomalocardia brasiliana (Gmelin, 1791) and Iphigenia brasiliana (Lamarck, 1818), this metacestode was observed near the digestive gland and gonad (Boehs et al., 2010). In Tapes semidecussata (Reeve, 1843) (Cheng and Rifkin, 1968), Crassostrea gigas (Thunberg, 1793) (Sabry and Magalhães, 2005), and C. rhizophorae (Sabry and Magalhães, 2005; Sabry et al.,

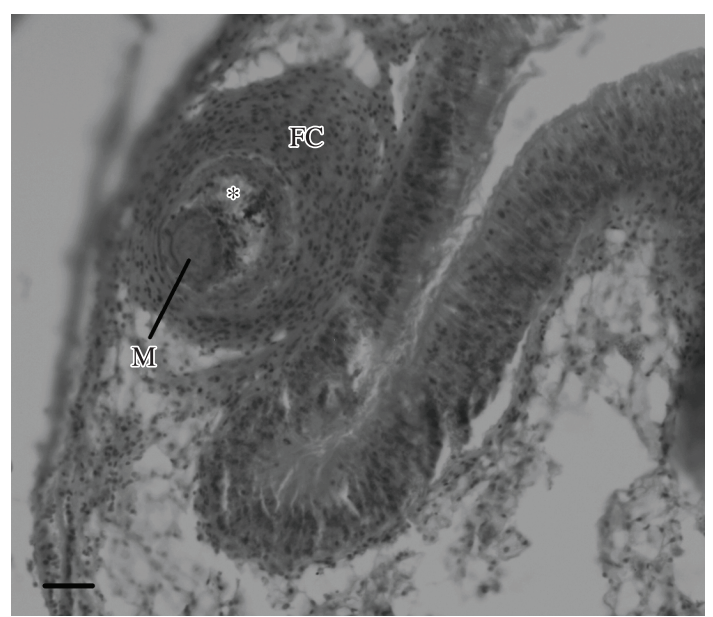

Figure 7. Tylocephalum sp. (*) in the mantle of Mytella guyanensis, showing fibrous capsule (FC) with hemocytic response and myzorhynchus (M) of metacestode. Scale bar $=20 \mu \mathrm{m}$. 
2007), this parasite was found only in the digestive gland. In all cases, metacestodes were encapsulated by host cells and fibers, although with no apparent damage to the host organs. In this study, the destruction and resorption of the metacestode were evident. These processes were also observed in T. semidecussata by Cheng and Rifkin (1968), C. rhizophorae by Sabry and Magalhães (2005), and A. brasiliana and I. brasiliana by Boehs et al. (2010). Therefore, the efficient inflammation and encapsulation reactions to this parasite, coupled with its generally low prevalence and degree of infection, reduce its effects on bivalve populations.

In conclusion, at present the health of $M$. guyanensis does not seem to be seriously threatened in the bay. This most probably reflects the good state of preservation of this area. However, considering the high prevalence of both the gregarine Nematopsis sp. throughout the period and RLOs during a few months of the year, as well as of potentially destructive digenean sporocysts, periodic monitoring of the health of this (and other molluscs) is recommended. It is also necessary to continue governmental and nongovernmental efforts to preserve the self-sustainability of the region.

Acknowledgements - The authors thank the Brazilian funding agencies FINEP and $\mathrm{CNPq}$ for financing the project, and CAPES for granting a scholarship to the first author. We also thank the NGO ORDEM, Elias Veloso, Ricardo O'Reilly and Tiago Lenz for their support in collecting; and Mariane Luz for her assistance in processing samples.

\section{References}

AZEVEDO, C. and CACHOLA, R., 1992. Fine structure of the Apicomplexa oocyst of Nematopsis sp. of two marine bivalve mollusks. Diseases of Aquatic Organisms, vol. 14, p. 69-73. http://dx.doi.org/10.3354/dao014069

AZEVEDO, C. and MATOS, E., 1999. Description of Nematopsis mytella n. sp. (Apicomplexa), parasite of the mussel Mytella guyanensis (Mytilidae) from the Amazon Estuary and description of its oocysts. European Journal of Protistology, vol. 35, p. 427-433. http://dx.doi.org/10.1016/S0932-4739(99)80052-2

BOEHS, G. and MAGALHÃES, ARM., 2004. Simbiontes associados com Anomalocardia brasiliana (Gmelin) (Mollusca, Bivalvia, Veneridae) na Ilha de Santa Catarina e região continental adjacente, Santa Catarina, Brasil. Revista Brasileira de Zoologia, vol. 21, p. 865-869. http://dx.doi.org/10.1590/S0101-81752004000400021

BOEHS, G., VILLALBA, A., CEUTA, LO. and LUZ, JR., 2010. Parasites of three commercially exploited bivalve mollusc species of the estuarine region of the Cachoeira River (Ilhéus, Bahia, Brazil). Journal of Invertebrate Pathology, vol. 103, p. 43-47. PMid:19850046. http://dx.doi.org/10.1016/j.jip.2009.10.008

BOWER, SM., 1992. Diseases and parasites of mussels. In GOSLING, E. (Ed.). Developments in Aquaculture and Fisheries Science: the mussel Mytilus: Ecology, Physiology, Genetics and Culture. Amsterdam: Elsevier. vol. 25, p. 543-563.

BOWER, SM., McGLADDERY, SE. and PRICE, IM., 1994. Synopsis of Infectious Diseases and Parasites of Commercially Exploited Shellfish. Annual Review of Fish Diseases, vol. 4, p. 1-199. http://dx.doi.org/10.1016/0959-8030(94)90028-0
CARBALLAL, MJ., IGLESIAS, D., SANTAMARINA, J., FERROSOTO, B. and VILLALBA, A., 2001. Parasites and pathologic conditions of the cockle Cerastoderma edule populations of the Coast of Galicia (NW Spain). Journal of Invertebrate Pathology, vol. 78, p. 87-97. PMid:11812111. http://dx.doi.org/10.1006/ jipa.2001.5049

CHENG, TC. and BURTON, RW., 1965. Relationships between Bucephalus sp. and Crassostrea virginica: Histopathology and sites of infection. Chesapeake Science, vol. 6, p. 3-16. http:// dx.doi.org/10.2307/1350618

CHENG, TC. and RIFKIN, E., 1968. The occurrence and resorption of Tylocephalum metacestodes in the clam Tapes semidecussata. Journal of Invertebrate Pathology, vol. 10, p. 65-69. http://dx.doi. org/10.1016/0022-2011(68)90264-4

CREMONTE, F., FIGUERAS, A. and BURRESON, EM., 2005. A histopathological survey of some commercially exploited bivalve molluscs in northern Patagonia, Argentina. Aquaculture, vol. 249, p. 23-33. http://dx.doi.org/10.1016/j.aquaculture.2005.01.024

DA SILVA, PM., CREMONTE, F., SABRY, R.C., ROSA, RD., CANTELLI, L. and BARRACCO, MA., 2009. Presence and histopathological effects of the Parvatrema sp. (Digenea, Gymnophallidae) in the stout razor clam Tagelus plebeius (Bivalvia, Psammobiidae). Journal of Invertebrate Pathology, vol. 102, p. 14-20. PMid:19500587. http://dx.doi.org/10.1016/j. jip.2009.05.014

DA SILVA, PM., MAGALHÃES, ARM. and BARRACCO, MA., 2002. Effects of Bucephalus sp. (Trematoda: Bucephalidae) on Perna perna mussels from a culture station in Ratones Grande Island, Brazil. Journal of Invertebrate Pathology, vol. 79, p. 154-162. http://dx.doi.org/10.1016/S0022-2011(02)00026-5

FRANCISCO, CJ., HERMIDA, MA. and SANTOS, MJ., 2010. Parasites and symbionts from Mytilus galloprovincialis (Lamarck, 1819) (Bivalves: Mytilidae) of the Aveiro Estuary Portugal. Journal of Parasitology, vol. 96, p. 200-205. PMid:19785477. http://dx.doi.org/10.1645/GE-2064.1

GARCIA, P. and MAGALHÃES, ARM., 2008. Protocolo de identificação e quantificação de bucefalose (enfermidade laranja) em mexilhões Perna perna. Boletim do Instituto de Pesca, vol. 34, p. 11-19.

LAUCKNER, G., 1983. Diseases of Mollusca: Bivalvia. In KINNE, O. (Ed.). Diseases of Marine Animals. Hamburg: Biologische Anstalt Helgoland. vol. 2, p. 477-879.

LIMA, FC., ABREU, MG. and MESQUITA, EFM., 2001. Monitoramento histopatológico de mexilhão Perna perna da Lagoa de Itaipu, Niterói, RJ. Arquivo Brasileiro de Medicina Veterinária e Zootecnia, vol. 53, p. 203-206.

LOWE, DM., SALKELD, PN. and CARR, MR., 1994. The effect of geographical location on the cellular composition of the mantle tissue of the mussel, Mytilus edulis. Journal of the Marine Biological Association of the United Kingdom, vol. 74, p. 225-232. http://dx.doi.org/10.1017/S0025315400035785

MARGOLIS, L., ESCH, GW., HOLMES, JC., KURIS, AM. and SCHAD, GA., 1982. The use of ecological terms in parasitology (report of an ad hoc Committee of the American Society of Parasitologists). Journal of Parasitology, vol. 98, p. 131-133. http://dx.doi.org/10.2307/3281335

MATOS, E., MATOS, P. and AZEVEDO, A., 2005. Observations on the intracytoplasmic microsporidian Steinhausia mytilovum, a parasite of mussel (Mytella guyanensis) oocytes from the Amazon 
River Estuary. Brazilian Journal of Morphological Sciences, vol. 22, p. 183-186.

NARCHI, W., 1966. Encontro de Bucephalopsis haimeana (Lacaze-Duthiers) no Brasil. Ciência e Cultura, vol. 18, p. 22-24.

NASCIMENTO, IA., SMITH, DH., KERN II, F. and PEREIRA, AS., 1986. Pathological findings in Crassostrea rhizophorae from Todos os Santos Bay, Bahia, Brazil. Journal of Invertebrate Pathology, vol. 47, p. 340-349. http://dx.doi.org/10.1016/00222011(86)90105-9

PAPERNA, I., 1995. Digenea (Phylum Platyhelminthes). In WOO, PTK. (Ed.). Fish Diseases and Disorders, Protozoan and Metazoan Infections. Cambridge: University Press. p. 329-389.

PINTO, TR. and BOEHS, G., 2008. Nematopsis sp. (Apicomplexa: Eugregarinida) em Mytella guyanensis (Lamarck, 1819) (Bivalvia: Mytilidae) da região estuarina do Rio Cachoeira, Ilhéus, Bahia, Brasil. Brazilian Journal of Veterinary Research and Animal Science, vol. 45, p. 95-100.

RIOS, EC., 2009. Compendium of Brazilian Sea Shells. Rio Grande: Evangraf. 668 p.

ROBLEDO, JAF., CÁCERES-MARTÍNEZ, J., SLUYS, R. and FIGUERAS, A., 1994. The parasitic turbellarian Urastoma cyprinae (Platyhelminthes: Urastomidae) from blue mussel Mytilus galloprovincialis in Spain: occurrence and pathology. Diseases of Aquatic Organisms, vol. 18, p. 203-210. http://dx.doi. org/10.3354/dao018203

SABRY, RC. and MAGALHÃES, AR., 2005. Parasitas em ostras de cultivo (Crassostrea rhizophorae e Crassostrea gigas) da Ponta do Sambaqui, Florianópolis, SC. Arquivo Brasileiro de Medicina Veterinária e Zootecnia, vol. 57, p. 194-203.

SABRY, RC., GESTEIRA, TCV. and BOEHS, G., 2007. First record of parasitism in the mangrove oyster Crassostrea rhizophorae (Bivalvia: Ostreidae) at Jaguaribe River estuary - Ceará, Brazil. Brazilian Journal of Biology, vol. 67, p. 755-758.

SHAW, BL. and BATTLE, HI., 1957. The gross and microscopic anatomy of the digestive tract of the oyster Crassostrea virginica (Gmelin). Canadian Journal of Zoology, vol. 35, p. 325-347. http://dx.doi.org/10.1139/z57-026

UMIJI, S., LUNETTA, JE. and LEONEL, RMV., 1976. Infestation of the mussel Perna perna by digenetic trematodes of the Bucephalidae family, gen. Bucephalus. Anais da Academia Brasileira de Ciências, vol. 47, p. 115-117.

VILLALBA, A., CARBALlAL, MJ., LÓPEZ, C., CABADA, A., CORRAL, L. and AZEVEDO, C., 1999. Branchial rickettsia-like infection associated with clam Venerupis rhomboides mortality. Diseases of Aquatic Organisms, vol. 36, p. 53-60. http://dx.doi. org/10.3354/dao036053

VILlALBA, A., MOURELlE, SG., CARBALlAL, MJ. and LÓPEZ, C., 1997. Symbionts and diseases of mussels Mytilus galloprovincialis throughout the culture process in the Rías of Galicia (NW Spain). Diseases of Aquatic Organisms, vol. 31, p. 127-139. http://dx.doi.org/10.3354/dao031127

WINSTEAD, JT., VOLETY, AK. and TOLLEY, SG., 2004. Parasitic and symbiotic fauna in oysters (Crassostrea virginica) collected from the Caloosahatchee River and estuary in Florida. Journal of Shellfish Research, vol. 23, p. 831-840. 
